\title{
The Ethics of Economic Development and Human Displacement
}

\author{
Des Gasper (International Institute of Social Studies, Erasmus University Rotterdam) ${ }^{i}$ \\ Pre-final version of chapter for 'The Oxford Handbook on Professional Economic Ethics', \\ editors George DeMartino and Deirdre McCloskey, Oxford University Press, 2014
}

\begin{abstract}
Development projects have frequently brought clashes between claims for improvement for powerful groups nationwide and worldwide and the rights of marginal groups in project-affected areas, leading to ruinous forced resettlement of the latter. Economic cost-benefit analysis based on the potential compensation principle endorses sacrifice of weaker groups' livelihoods and rights for the sake of benefits for groups in which many members are already (much) better off. The chapter examines and links two lines of response: the ethic of responsibilities from Penz, Drydyk and Bose, based on studying dam projects and the 'human development ethic' embedded in existing international agreements; and human rights-based approaches elaborated for mining projects. A global language of human rights, including principles of recognition, accountability and participation, proves a vital medium for mobilising and linking local and international civil society groups and getting seats for weaker local groups at project negotiating tables, which can then allow processes of mutual learning and accommodation. Serious attention to these principles and standards, together with other elements of a human development ethic and responsible development, should become routine in economists' training and practice.
\end{abstract}

Keywords: development ethics; displacement; development projects; cost-benefit analysis; compensation principle; rights-based approaches social movements

\section{INTRODUCTION - BEYOND THE ECONOMIST'S OATH}

Economic development raises painful ethical questions. The example we consider in this paper is the displacement of people from their homes and livelihoods, and the associated ethical conundrums. The questions cannot be adequately answered by the conventional methods of economics. This does not mean that economists can conveniently leave the ethical questions purely for an often absent notional 'colleague' from another discipline or an authorized decision-maker. The latter often readily resorts to the recommendations generated by the conventional methods of economics. In market-based societies these methods, the expression of a private business rationality, are accepted as common-sense, even as neutral or natural; they are familiar, apparently precise, and part of a larger world-view that offers impersonal justifications. Yet development processes in which (to use the formulation by Michael Cernea) the same groups consistently reap the gains while other groups consistently suffer the pains are immoral.

Nor may the professional economic ethics presented in George DeMartino's The Economist's Oath suffice, relevant though it is in embodying a stance of accepting responsibility and accountability. The proposed Oath appears based on an analogy to the medical Hippocratic Oath. 
But most economists do not work as clinicians in direct contact with single, suffering or needy, patients. Instead they work as employees or advisers to power-holders-governments, businesses, banks, international agencies-whose actions impact thousands, millions, even sometimes hundreds of millions of persons, including often beyond any single legal jurisdiction. Sometimes they become power-holders themselves. If engaged in research they, unlike medical scientists or other social scientists, rarely have direct contact with ordinary people; instead typically they process statistics produced by other agencies. The Oath's acknowledgement of economists' great potential influence, including great potential to advance actions that seriously harm many people, and of corresponding ethical obligations - to consult, reflect, think deeply about the limits of their own arguments, and seek to minimize harm-are strongly to be welcomed. The means for seeking to respect these ethical obligations must take partly different forms than those normal for medical practitioners or field anthropologists, to reflect the more indirect and generalized mechanisms through which economists typically work.

First, economists' methodologies, not only their personal use of tools, must come under ethical scrutiny. Notably, economic cost-benefit analysis as an approach to evaluation of public choices is enormously ethically deficient for many cases and purposes (see e.g.: Maclntyre 1977, Shue 2006, Penz et al. 2011), both in theory and (especially) in use. The relationship of economics research and advice to non-utilitarian ethical systems, including those of human rights and human development thinking, demands close attention in economics training and practice (see e.g. Gasper and St. Clair 2010). Good practice by economists cannot draw only on distinctively economic concepts (DeMartino 2011: 105).

Second, the ethically aware self-consciousness required of economists must include attention to their societal insertion and roles, and the forms of their relationship to publics and not only to those who pay for their services. In this context, we need attention to procedural requirements set by values of human rights and democracy, and to the roles of social movements and agencies that seek to articulate and defend such rights and to counterbalance the pulls of payment-for-service.

Third, often the do-no-harm principle cannot be fulfilled: not only cannot all consequences be foreseen, but ethically desirable material progress depends on development projects which inevitably displace some people, and full remedial compensation appears not always possible. Hence, a principle of free, prior and informed consent would give every group (including rich groups) a veto over changes which bring them net costs. In some cases, displacement of one disadvantaged group might be necessary for major improvement in the lives of much larger and equally or more disadvantaged groups. The Economist's Oath sometimes highlights the principle "do no harm", but the oath presented in its final chapter (p.232) involves a more feasible commitment: to minimize harm. How?

Relevant thinking about dangers, ideals, constraints, and how still to pursue the ideals, has been undertaken in the field of development ethics since at least the 1950s (see e.g.: Goulet 1960, 1971; Malley 1968; Berger 1974; Gasper and St.Clair 2010; Penz, Drydyk, Bose 2011). However the majority of economists have remained content with principles of utilitarianism, as transmuted into the format of economic cost-benefit analysis which not merely adopts the Kaldor-Hicks principle of potential compensation rather than actual compensation but measures gains and losses in terms of willingness and ability to pay, thus ignoring both non-monetizable values and the value of those people with little or no ability to pay. I have called this stance 'money-tarianism' (Gasper, 2004). The language of human rights, for example, remains unknown in nearly all economics teaching, and is deliberately avoided by the most powerful international development agency, the World Bank 
(McNeill and St.Clair 2009; Gasper et al. 2013). It is also absent from the index of The Economist's Oath.

Development projects displace an estimated ten to fifteen million people per year who are directly forced to vacate their location of residence or work when it is requisitioned for or made uninhabitable by other activities. The issue has been considered in work on development ethics, including with special reference to dams projects. In recent years it has been examined in depth, as by the World Commission on Dams (2000), in reaction to increased pressures to put 'international competitiveness first, at the expense of intra-national distributive justice', including by downplaying the social costs of projects (Penz et al., 2011: 255). Similarly, as enormously disruptive and landusing new technologies of open-cast mining have spread, a body of work on rights-based approaches to proposed mining projects has emerged. ${ }^{1}$

Chris de Wet asks 'Does Development Displace Ethics?', for in his view the notion of compensation fails and the clash between the right to development and the rights of potential displacees cannot be well resolved (de Wet, 2009). Eviction is inherently such a disruptive and stressful event, and resettlement such a complex and uncontrollable exercise, that displacees cannot in general be adequately compensated, given what they require and what development managers can deliver. De Wet's view reflects a mood of depression in the literature on dams, displacement and forced resettlement, after decades of research that has revealed enormous victimization, and decades of discussion of remedial guidelines that then in practice become diluted and often largely ignored.

This paper considers two complementary lines of response. First is the ethic of responsibilities proposed by Peter Penz and colleagues regarding development-induced displacement (Penz et al. 2011). They build a system of ethical guidelines for local, national and international responsibilities, with special reference to dam projects; it is based on a synthesis of core values that they believe constitute a widely officially accepted 'human development ethic'. Such work goes beyond DeMartino and may evoke optimism through being able to identify reasonable principles, not highly specific to a particular philosophical and cultural tradition but still with important implications. What give principles force, however, are bases of power, such as through embedding of the principles in social movements (cf. Stammers, 2009).

So, second, we will consider the human rights-based approaches that have been elaborated to deal for example with conflicts over proposed new mining projects. This literature is more upbeat than that over dams, given some emblematic cases of local success and recent national cases of advance (Bolivia and Ecuador; Bebbington et al., 2008a, 2008b). The work has both an explicit ethical basis and a focus on the social and political dynamics of conflicts. Proponents of a human rights-based approach argue that it helps us in explaining and transforming mining conflicts (Echave et al. 2009). It can help to explain, because if core rights are not respected then conflict is (more) likely to ensue or intensify. It can help to transform, by indicating how respect for human rights and their institutionalisation can establish bases for mutually fruitful local dialogue and cooperation. Some experiences suggest the value of processes of encounter, of building trust and legitimacy, and joint search for solutions; but also the need for backing for local resistors from national and international movements of change. Here too the global language of human rights has a key role: its relatively widely agreed legitimacy and significant degree of institutionalisation can

\footnotetext{
${ }^{1}$ The largest gold mine in the world, the Grasberg mine in West Papua, for example, reportedly generates 700,000 tons of waste per day and could eventually affect about 100 square miles of territory (Earthworks and Oxfam America, 2007).
} 
help in establishing the required processes of respectful encounter, negotiation, and alliance building, locally, nationally and internationally.

\section{ECONOMIC DEVELOPMENT AND HUMAN DISPLACEMENT: does development displace ethics?}

A widely cited figure for the scale of development-forced displacement in the early $21^{\text {st }}$ century was fifteen million people per year, up from perhaps ten million per year in the late 20th century (de Wet 2009 and Oliver-Smith 2009). The estimates come originally from Michael Cernea, doyen of displacement studies, the first sociologist in the World Bank and for many years a lonely voice there. 'These figures do not include the even broader processes of incidental and indirect displacement' (Penz et al. 2011:2). ${ }^{2}$ Displacement on such a scale is likely to continue. The rapid growth of mega-cities brings displacement within and adjacent to the cities, and also requires transfers of food, energy and water from far away, which bring demands for new large dams (Scudder 2005).

Displaced people are subject to many types of risk: landlessness, joblessness, homelessness, marginalization, food insecurity, increased morbidity, loss of access to common property resources, and social disarticulation (Cernea, 2000). In addition, those who are displaced or at risk of displacement are profoundly stressed by their exclusion from knowledge and control about what will happen to them. From a distance, unfortunately, we can be rather sure about what that will eventually be, if past practice continues. For 'the record of dismal failures and concomitant pain and suffering for the displaced continues with depressing regularity', notes another veteran of displacement studies (Oliver-Smith, 2009: 17), citing also Cernea (2009). ${ }^{3}$ In general, of low- and middle-income countries only those which have had to take donor loans with conditions concerning procedures and compensation have undertaken careful assessment of options and serious compensation in development projects. Even where compensation exercises exist: 'Overwhelming evidence documents pervasive and multidimensional distortions of compensation in practice' (Cernea, 2008: 56).

The losses, resulting vulnerabilities, and rending of structures and meanings are not equally shared. Some people, very largely already worse off, lose-drastically-so that others, largely already (much) better off, may gain. Thirty-six of the forty-four dam resettlement cases reviewed by Scudder (2005) showed direct material losses to the displaced. Economic cost-benefit analysis requires only potential, not actual, compensation, of victims; whether to compensate is left for determination by those in power. Penz et al. note that for the method's creators the 'gains and losses from public projects were implicitly thought to be widely dispersed gains and losses that are relatively small for everyone' (2011: 76). Displacement shatters this assumption. But in the predominant implicit theory of citizenship, one's rights flow from and are secondary to being a member of a viable and thriving nation. In the same way that a conscript soldier's family may in many cases get little compensation if he strays 'into the way of a bullet', a community is widely considered duty-bound to bear the sacrifice if they happen to be located in the way of development' (Blaser et al., 2004; Dwivedi, 2006).

\footnotetext{
2 Penz et al. (2011) define different types of displacement, direct or indirect, by eviction or threat or inducement; including the case where people do not migrate but are barred access to local resources on which they have traditionally relied.

${ }^{3}$ See, e.g., the record in India, reviewed in detail in Perspectives (2008), which estimated well over sixty million people displaced since 1947.
} 
Dwivedi (2002) identified a set of alternative current responses to potential dam-induced displacement, a classification which is adopted with modified labels by Penz et al. (2011): (1) 'reformist-managerial' ('managerialist' for Penz et al.); (2) 'radical-movementist' ('radicalstructuralist'), and (3) 'institutional' ('responsibility'). (See also Dwivedi, 2006, Ch.9.) In reality, the most prevalent approach has lain outside this list: it has been to crush or sweep aside those who stand 'in the way of development'. We may call that the 'bulldozer' approach (\#4). Managerial reformists see development projects and therefore displacement as necessary, and as matters to be decided at national level; but they at least seek in a second stage of consideration to minimize displacement's undesirable features. Contrary to Dwivedi (2002: 730), though, not all managerialists are managerial-reformists. Many are not interested in a second stage, of amelioration; instead they administer the bulldozer. At the opposite pole, the 'radical structuralist' approach says there are no solutions under capitalism, and 'movementist' approaches insist on the veto rights of local peoples. Such approaches are sceptical about the quantity and quality of the claimed benefits and estimated costs of development projects, as well as outraged at the typical distribution of actual costs and benefits across different groups. In between the poles, Penz et al.'s responsibility approach 'rooted in development ethics is [proposed as] a productive way of starting to bridge the gap between movementist and managerial [reformist] concerns' (2011: 288). It proposes that local people have extensive rights, but not of veto; and seeks to work out the rights and duties of each of a wide range of actors, both national and inter-national.

Responding to the prevalence of 'bulldozer' development, displacement has been discussed in the literature on development ethics since its outset, as in classic statements by Denis Goulet (1971) and Peter Berger (1974). But, says de Wet (2009), in reality development displaces ethics as well as people: decision-makers in development-forced displacement and resettlement projects find themselves unable to refuse projects that they are at the same time unable to ethically justify. There is arguably an inherent clash between rights to development and the livelihood rights of inhabitants in the affected locality who face displacement. New projects that will promote human well-being in the aggregate and will benefit, directly or eventually, large numbers of poor people, inevitably bring costs to many people whose homes and workplaces lie 'in the way of development'. And, for the following reasons, for many of those people the costs will be irreparable.

First, contingent but very probable factors increase the exposure of the at-risk inhabitants: projects will be rushed and politically driven; and the at-risk populations come typically from weaker and often ethnically distinct groups who are easily denigrated, pushed aside-for example because they lack formal legal title to land-and forgotten (Oliver-Smith ed., 2009). The worldwide record of treatment of displaced populations involves large-scale dispossession, not just 'displacement'.

Second, fundamental features of resettlement mean it is very likely to bring irreparable damage to the displaced. Displacement involves not just loss of place and of economic assets, it typically brings losses of organization, identity and meaning (Downing \& Garcia-Downing, 2009; de Wet, 2009). The stresses of involuntary relocation and resettlement-physiological, psychological, and socio-cultural, according to the famous Scudder-Colson model derived from their studies of the impacts of the Kariba Dam on the Zambezi River-are permanent rather than temporary. There are stresses of having moved, not only stresses of the move. Costs of loss of meaning are major, and not only for displaced indigenous peoples; they affect many displaced persons. Some people lose their tranquillity, their sense of purpose, their psychological grip; some become mentally ill. Social disintegration is hard to avoid because earlier social balance was the product of long trial and error. 
Disintegration cannot readily be subsequently tidied up, remedied or counterbalanced by a bit of economic investment (Downing \& Garcia-Downing, 2009).

Thirdly, continues de Wet, the complexities of resettlement are enormous and uncontrollable. Administrative, cognitive and material limits mean that compensation adequate for disrupted population groups often cannot be ensured even if the will existed. Suitable alternative land or jobs may not be available. And both official agencies and popular groups lack capacity to understand, to negotiate and to find creative solutions. '[Cernea finds that resettlement] projects are consistently underfinanced because of a failure to understand the nature and extent of losses and needs' (Oliver-Smith, 2009: 17). We saw that Scudder (2005) found sufficient compensation in only eight out of 44 large dam cases that had been studied; and in only three of the cases had the displaced people shared in the net gains from the project.

Faced with such profound conflicts and scarcities of understanding and capacity, ethics too is displaced, concludes de Wet. It cannot give us guidance that will justify us in sleeping quietly. All it can tell us is that projects which are purely for minority interests should be rejected. Projects for the greater public good can be accepted, but with sadly no assurance that the victims can and will be adequately protected - though we must try our best to ensure it, including by studying the particularities of each case and by seeking to widen sympathies across society.

What of creative innovation to find mutually beneficial solutions, as the policy analysis literature exhorts (e.g., Forester, 2009) ? The chapter on creative problem-solving in The Oxford Handbook of Public Policy opens with the challenge set by a prospective dam (Winship, 2006). The site of the prospective Orme Dam in Arizona, at the confluence of two rivers close to a fast growing metropolis, fulfilled the standard engineering, aesthetic and economic criteria for constructing an inspiring structure that would be a cathedral of the nation and simultaneously a vast economic enterprise. The government was willing to pay enormously for the site. But the potential resulting lake would cover the ancestral homeland of the Yavapai people. The price was irrelevant to them: 'The land is our mother. You don't sell your mother.' In 1970s America, unlike in many other countries or in the USA of the previous century, the indigenous group had a strong enough legal and political position to block the project. During the following decade, new-style engineers joined the government agency responsible, the Bureau of Reclamation, engineers who had trained not only to plan huge dams but to conceive of alternatives and to compare them through economic costbenefit analysis. An equally economically attractive alternative design emerged: a series of smaller dams that avoided displacement of the Yavapai. Note that although cost-benefit analysis was required to persuade economists and engineers, it did not itself address the concerns of the Yavapai, so that other elements of fresh thinking were needed for a solution that satisfied all parties despite their very different values.

De Wet is aware of such possibilities in some cases, but he considers that they are too rarely available to offer much relief (2009: 89). As implied by the Orme Dam case, however, the very complexity of such development enterprises, exceeding the capacity of any government to control, can provide opportunities for advance through new ideas if space is created for various actors to participate, meet, argue, and generate and share such ideas (Oliver-Smith, 2009; Dwivedi, 2006, Ch.10). Social movements may have more potential here to influence attitudes, the identification of alternatives, and the whole terms of engagement, than do journal discussions amongst academics or conclaves only of politicians, planners and economists (Baviskar, 2006). 


\section{A PROPOSED ETHICS OF HARM AVOIDANCE AND REDUCTION - The Penz-Drydyk-Bose synthesis}

Penz, Drydyk and Bose's Displacement by Development - Ethics, Rights and Responsibilities (2011) offers a systematic ethical response to displacement dilemmas: an attempted response to the ethical blindness of economic cost-benefit analysis, the rigidity and veto-powers created by simple human rights formulations, and the pessimism articulated by de Wet. The lead author, Peter Penz, is originally a welfare economist. The second author, Jay Drydyk, is a former President of the International Development Ethics Association.

Penz's early work explored the normative criterion of consumer sovereignty which underlies market-based evaluation and cost-benefit analysis (Penz 1986). From identification of strengths and also serious weaknesses in the criterion, including its acceptance of the existing distribution of purchasing power, he considered and tested alternative public policy criteria. Here he arrived at a conception of basic human needs, as intersubjectively established societal priorities, derived from core criteria of health (physical and mental), social inclusion, and happiness. Testing of this conception was done by application of the various criteria to the performance of several different ideal-type economic systems. Penz's work had a major influence on the seminal A Theory of Human Need (1991) by Len Doyal and lan Gough, probably the best known modern statement on needs ethics and needs-based policy, and also contributed indirectly to the theoretical foundations for the UNDP 'Human Development Approach', which was launched in 1990, by a team including Paul Streeten, Penz's former PhD supervisor.

Penz, Drydyk and Bose synthesise such ideas and much more, to provide a massive elaboration of a development ethic that offers guidance on displacement issues. They seek thereby to ground more solidly, amend and extend, the principles presented by the World Commission on Dams: accountability, efficiency, equity, sustainability and participatory decision-making. Much of their argumentation is within a human rights framework, delineating rights and responsibilities. They use in effect a conception of rights known as 'goal-rights' (Sen, 1982): the fulfilment of identified rights has finite weight, like the achievement of other goals, not an overriding status. Rights fulfilment must be balanced against other goals, including not least the fulfilment of other rights. A right to property, for example, is no argument against a duty to pay taxation to support shared systems of law, education, public health and infrastructure - and systems for compensation to displaced people. Penz et al.'s stance is also pragmatic methodologically. Rather than seeking to adopt and apply any single ethical theory, or simply to rely on intuition or regnant community values, ${ }^{4}$ they follow an intermediate approach that 'focuses on generalisable principles, but does not commit itself to a particular normative theory' such as utilitarianism, Kantianism or Rawlsianism (Penz, 2003: 142).

Penz et al.'s proposal follows in the footsteps of the World Commission on Dams and has three elements:

1. the development for which the displacement is required must be shown to satisfy the values of 'responsible development' (2011: 13), namely not merely economic growth but a) promotion of human well-being and security, and respect for b) equity, c) participation and empowerment, d) cultural freedom, e) environmental sustainability, and f) (other) human rights including respect for fair procedure;

\footnotetext{
4 The formulation in DeMartino's Oath - 'to enhance the capabilities of that community to undertake those innovations that it deems desirable and achievable' (p.232) - leaves some risk that the 'community' voice is that of elite groups.
} 
2. the treatment of displaced people must itself satisfy those values: the displaced people 'should not be victimized; ...on the contrary, they should share in the benefits of the projects that displace them; and...they should be empowered rather than disempowered by the process' (2011: 13);

3. procedures for adjudication of claims and disputes must be provided, on an ethically justified basis, including participation by those affected and with adjudication completed at each stage before proceeding to the next.

The proposed values of responsible human development derive from a principle of 'nonmaleficence' - a core value of 'minimizing harm and neglect' (2011: 118)-that matches the commitment in DeMartino's Oath to '[take] care to minimize harm' but is more refined. ${ }^{5}$ Similarly to rule-utilitarianism, the principle is used for judging systems of moral ideas rather than as a direct prescription to all individual agents. As a principle to guide policy, it goes further than only avoiding directly doing harm, to include trying to reduce and prevent avoidable harm, and so can be called a principle of harm reduction, minimization or avoidance. From this core value Penz et al. argue towards the more specific (sets of) values mentioned above, that have all become widely adopted in international organizations and international declarations.

They hold that such 'a development ethics approach offers a fundamental and necessary shift in focus from a conception of development that is rooted in aggregate welfare to one that foregrounds not only distributive justice but also self-determination' (Penz et al., 2011: 289). A style of development which suppresses the latter two values is very unlikely in the long run to promote aggregate welfare either, for it sows seeds of social malaise and conflict. Penz et al. are perhaps overly sanguine, though, on the extent of value consensus, including around the interpretation of distributive justice. Reviewing several large global value surveys, Kates et al. (2006) found that whereas large majorities worldwide are concerned about the weak (children, the elderly, sick and disabled), views are divided about poverty. Large majorities in Pacific Rim countries, including the USA and China, blame poverty on laziness and lack of willpower; whereas majorities elsewhere stress lack of fair opportunities as the main cause.

Penz et al.'s ethic seeks to minimise displacement, by ensuring realistic inclusive assessment of its costs and alternatives, but can permit it when there is equitable compensation. In contrast to the "bulldozer ethic's positing of a duty of sacrifice by the unfortunates who live 'in the way of development', Penz, Drydyk and Bose stress that sacrifices required by any development projects that are in the general interest must be shared equitably not arbitrarily, i.e. not imposed disproportionately on those who happen to live in a project location. If the project is justified then the polity can afford to provide adequate compensation to those who suffer from the project (provided that their holdings were legitimate, and that priority goes to compensation for the most needy), and it must ensure their ability to share in project benefits. When identification of damage on a per individual basis is difficult, compensation may be paid instead to a local community or regional government.

Element 3 of the proposal, on participation, follows the World Commission on Dams. Whereas when the people at risk of displacement are 'Indigenous and Tribal Peoples', ILO Convention No. 169 of 1989 and the 2007 UN General Assembly Declaration on Rights of Indigenous Peoples give them a veto right, the World Commission proposed instead for all peoples a right of participation and negotiation at all stages of project planning and decision-making, including on the type of project and whether it was justified; 'within these procedures, development does not

\footnotetext{
${ }^{5}$ DeMartino (2011:123-6) discusses treatments of non-maleficence in medical ethics and environmental ethics.
} 
proceed from one stage to the next unless adequate adquate commitments to deliberation, negotiation and adjudication have been made, fulfilled and verified' (Penz et al., 2011: 113). When the required consultation, search for alternatives, assessment of social and environmental costs, etcetera have not been competently completed, then adjudication authorities-notably the courts-should have the power to halt a project. In this way the World Commission sought to advance beyond the managerialist versus movementist impasse. Displacement could sometimes be found necessary, but the assessment must be through broad and fair consultation and deliberation. A government, even if fairly elected, does not have the right to do whatsoever it chooses; its proposals on major issues should be tested by extensive public discussion that meets requirements set in deliberative democracy theory.

'Rather than leave forced development to an administrative process that paternalistically determines what the displaced are entitled to, the approach that commends itself is one of negotiation between the two parties of developers and the potentially affected, with access to adjudication based on explicit rules...' (Penz et al., 2011: 235). Such rules are to draw from international law and conventions. The principles of just process are the most disputed; managerialists may more readily accept principles on paper of compensation and of sharing in benefits, but typically become quiet on a share in decisionmaking, for that impinges on their authority and on how the paper principles are really used. The World Commission's proposal has hardly been adopted. International funding organisations, led by the World Bank, sidelined its work, and national governments followed suit. To national governments the relevant independent adjudicator is, by definition, themselves; even if a Ministry of Water or of Mines might perhaps be deemed a partisan stakeholder, governments deem an Office of the President, Ministry of Finance or National Assembly to be the representative of the general interest.

Besides the rights of the people at risk, Penz, Drydyk and Bose examine the responsibilities of the agencies whose actions may harm or benefit them, responsibilities that derive from the rights of the vulnerable and are binding specific duties. They stress the difference from charity of this responsibility to compensate for harm done. Penz et al. identify four salient rights and the associated responsibilities. First comes people's right to receive good reasons. It brings responsibilities for all agents in the public sphere, to facilitate and abide by the outcomes of fair public deliberation, and to block proposals that violate the 'values of responsible human development'. Second is a right to avoid victimization, which brings counterpart public responsibilities to identify all types of losses (definite and potential) and losers, and to try to prevent or mitigate losses. Third is the right to equitably share in benefits, which brings accompanying public responsibilities for making such arrangements. This right to benefit-sharing sometimes renders acceptable what might otherwise be adjudged as high demands for compensation. Further, non-niggardly compensation is sometimes justifiable as fruitful investment. Fourth comes a right to empowerment, that implies some responsibilities on others to provide timely and adequate information and to ensure fair representation of, negotiation with, and accountability to those affected by a project. Penz et al. consider how such responsibilities are distributed amongst public, private, civil-society and community agencies, both national and international. Where a damage-doer is clearly identifiable, it must pay the compensation. Thus, 'the risks involved in relocation should be borne primarily by the development agent' (2011:220). Where the damage-doer is not sharply identifiable, compensation becomes a government responsibility, including sometimes a responsibility for foreign governments, on the principle that the relevant government level is one that covers the relevant damage-doers (for example, corporations who 
have foreign headquarters) and that can tax them. Their book illustratively applies these principles to India's famous Narmada Valley dams.

Penz, Drydyk and Bose conclude: 'the development ethics approach allows for greater flexibility, breadth and appropriateness by drawing on more than international law as its foundation. By basing our approach on several key principles of "good development" and by enumerating rights of non-victimization, benefit-sharing, good reason and empowerment, we are able to consider displacement as more than an individual project phenomenon. It allows us to examine the roles of private capital, civil society, and both national and international development strategies as part of the evaluation of particular situations.' (Penz et al. 2011: 298).

Who will sustain these complex and protracted processes of assessment, negotiation and adjudication? Essential partners for the forms of analysis described by Penz et al. are social movements and civil society organizations that support and represent (in deeds as well as in words) the claims of the weakest groups in national and global society (Goulet, 2005). While codes of practice on displacement have gained some support from inter-governmental funding agencies, shifts in funding from multilateral to private banks and to less socially concerned foreign governments and less embarrassable investors have partly sidelined the painstakingly achieved ethical codes for investments (Johnston and Garcia-Downing, 2004). Social movements' role is therefore crucial (Khagram, 2004), although continued adequate State capacity and authority remain essential too. Penz et al. consciously try to move beyond just appeals to any enlightened technocrats in donor organisations and government Ministries, which was the orientation that Dwivedi (2002) argued had fundamentally limited the work of, for example, Cernea. We need therefore to clarify the roles for social movements, in influencing norms, exerting pressure and increasing capacity, and the international connections that provide essential support to local movements for human rights.

\section{SITUATING, LOCALLY AND GLOBALLY, HUMAN RIGHTS FOR PARTICIPATION IN DECISION-MAKING}

Human rights thinking directly responds to the neglect of those who are most vulnerable and excluded. But it has long faced the dilemma discussed by de Wet: the clash of different rights, each deemed absolute (Gasper, 2009). Further, while rights thinking tries to set firm standards and limits, we saw that in practice compensation arrangements typically become undermined and even ignored. Besides the dramatic undercounting of human and environmental costs, projects often systematically underestimate other costs, exaggerate benefits, and manipulate other aspects of assessment in order to get approval. Project choice often involves partisan manipulation rather than application of even a utilitarian or money-tarian ethic. ${ }^{6}$

'Human rights based approaches' (HRBAs) have therefore moved on, firstly to stress the rights to equitable procedures and accountability in decisionmaking (Newell and Wheeler, 2006), including to check counts and estimates, and secondly to incorporate insights from conflict resolution theory (Menkel-Meadow, 1996). Required are not simply declarations of particular rights but a 'human rights culture' which includes the principles of accountability, transparency and the like, and, underlying those principles, sufficient feelings of mutual respect and community. Conflict

${ }^{6}$ See, e.g.: Flyvberg (2008) on large construction projects worldwide; Porter et al. (1991) for a typical large development project in Kenya; Singh (1990) on cost overruns and performance shortfalls in dam construction in India; and Alvares and Billorey (1988) and Dwivedi (2006) on omissions and double-counting etc. in the Narmada dam appraisals. 
theory suggests that without mutual interaction of the stakeholders then the essential bases of respect, trust and co-operation are unlikely to be achieved, but that such processes usually require a long time and that negative situations cannot be easily reversed.

HRBAs in mining, for example, have been elaborated and disseminated by the Oxfam group. Oxfam Australia in particular has advocated a principle of 'free, prior and informed consent' (FPIC) of local communities in disputes over new investments in their localities. It has, like the World Commission on Dams, extended this principle beyond only indigenous peoples, who already have such standing in certain intergovernmental declarations, to insist that: 'Non-indigenous, projectaffected peoples have the right to consultation and negotiation in decision-making processes in ways that are consistent with the principles underlying the right to FPIC' (Oxfam Australia, 2010: 3). First, Oxfam Australia has presented FPIC as an implication from various basic human rights, and held that, like those basic rights, it therefore 'cannot be overridden on the grounds of protecting national interest or state ownership of subsoil resource rights' (Oxfam Australia, 2007: 9). Second, and taking us beyond disputes over which agreed international document has which areas of application and which degree of force, Oxfam Australia has proffered to companies and governments a principle of prudence: 'pursuing projects without obtaining the consent of local communities and Indigenous Peoples is not financially sustainable' (ibid.: 4). Projects require a local 'social licence' in order to operate satisfactorily, not only a government licence. Rio Tinto Zinc reportedly, if ambiguously, states 'that it recognises the need to respect the ability of nonindigenous local communities [too] to withhold consent' (cited by ibid.: 13).

The casus classicus cited by Oxfam Australia to illustrate 'mining companies recognising and respecting the right of communities to FPIC' was the Tintaya mine in Peru (loc. cit.). Let us look at that case, to consider how far it illustrates FPIC, Penz et al.'s proposed arrangements of negotiation and arbitration, and/or any other principles. ${ }^{7}$ The case is used to raise hypotheses, rather than investigated in depth in its own right. In the altiplano of southern Peru the state-run Tintaya copper mine opened in the 1980s after expropriation of 2400 hectares from a peasant community. The community officially filed its objection, to no avail. The mine was privatized in the 1990s, and eventually acquired by a group that became part of BHP Billiton, an Australian-British conglomerate that is one of the two largest mineral groups in the world. It aggressively expanded operations and more than doubled the mine's landholding. Widespread local dissatisfaction at its methods led to a 2001 report by the Peruvian NGO CooperAcción, which found that the land acquisitions had often been irregular: extremely underpriced, arranged in deals with local leaders who had no authorization to sell, and leading to forced evictions and loss of livelihood. The communities obtained support from Oxfam America to commission the Oxfam Mining Ombudsman based in Australia to examine their grievances. Until closed in 2009, this Ombudsman unit investigated grievances concerning Australian mining companies.

In early 2002 the Tintaya Dialogue Table (Mesa de Diálogo de Tintaya) was established, including BHP Billiton, the five Quechua-speaking local communities, and the mayor of the province, plus the National Coordinating Committee of Communities Affected by Mining (CONACAMI). its regional counterpart (CORECAMI), and representatives of Oxfam America and CooperAcción. The local communities insisted that central government agencies must not be invited. This reflected the national history of dispossession and exclusion, as a result of which the state is typically not trusted

\footnotetext{
7 This discussion draws especially on Echave et al. $(2006,2009)$ and Merino $(2008)$. Tintaya is an open pit mine at over 4,000 metres elevation in Cusco region. In 1999 it processed more than 16000 metric tonnes per day of skarn Cu ores (http://www.infomine.com/minesite/minesite.asp?site=tintaya).
} 
as a protector of local community interests and is seen locally as the ally of the mining company (Merino, 2008: 40). The Dialogue Table was co-funded by participants. Several months were used for familiarization, and brought acknowledgement that problems existed which needed to be tackled jointly, plus agreement to undertake a set of joint review studies. In the following phase, commissions to undertake the studies were formed, led by representatives of the local communities and by CORECAMI, and went to work from late 2002. The Land Commission evaluated, modified, accepted and then supervised the company's proposal to acquire and develop land to resettle displaced people. The Environment Commission conducted and commissioned a series of studies on the mine's impacts on the physical environment and on human and animal health. It found that some grievances were correctly attributable to the mine but some were not. The Human Rights Commission commissioned an independent institute to investigate other alleged human rights violations related to the mine, such as cases of eviction and violence, and to make recommendations. These eventually included that the mining company should publicly accept responsibility for various adverse impacts on the lives of local people, provide assistance in confirmed cases of individual violations, and invest in general support to local communities, including investment in better company-community relations. The Sustainable Development Commission looked at longer-term development options for the area and promoted preparation of plans by communities. A Coordination Commission helped to maintain momentum and trust. Reflecting the considerable progress, an agreement was signed in late 2004: to record the specific agreements in these various areas; to consolidate the Dialogue Table as a standing body for ongoing negotiation and follow-up; and to commit (modest) company funds for the remedial activities. In addition the company had agreed to commit up to $3 \%$ of pre-tax profits to the provincial government's programmes, and supported local community projects in some other ways.

In assessing this case one must be aware of the desire of both the company and the national and international NGOs involved to report an inspirational model. Some exaggerations may have entered the literature for wider publics. The research literature describes the ups and downs, tensions and limitations in the process. For Arellano (2008: 35) this is simply a case where 'an individual mining company uses the rhetoric of promoting local development to gain local support through clientelism, offering local communities...infrastructure development, marginal jobs and other benefits in exchange for a peaceful coexistence.' Tintaya is also not an example of FPIC for a major new investment; the case concerns not whether to permit or close a mine, but the rectification of an existing investment, through institutionalised trust-building and negotiation. Further, the area has a long tradition of mining activity, and agriculture is for survival only, so that mining is locally accepted as centrally important. Even so, by 2012 the local communities were less easily placated. In that year the central government declared a state of emergency in response to local unrest, objections to ongoing pollution, and campaign demands that the mining company now share not $3 \%$ but $30 \%$ of its profits: a serious sharing of gains, not only crumbs. ${ }^{8}$

Nevertheless the Tintaya Dialogue Table did represent an atypical advance-the transformation of an emergent conflict before it could deepen into violent actions that would make dialogue impossible; and BHP Billiton committed itself to 'seek prior consent' for new projects on communities' lands, not only get central government clearance (Echave et al., 2006: 46). The key features deserve attention. One is that participation by local communities in the negotiation was voluntary; it felt self-initiated and non-coerced. Second, vitally, 'mechanisms...now exist in the

8 In 2006-7 the mine was sold to Xstrata. On the 2012 unrest see e.g. Peruvian Times, 1 June 2012, http://www.peruviantimes.com/01/business-federation-calls-population-to-reject-mine-protests/15885/ 
international sphere that, when used correctly, can be very helpful for communities' (Echave et al., 2006: 39). 'There is no doubt that the presentation of the case involving the five communities near the Tintaya mine to the Mining Ombudsman's Office in Australia [had] worried the mining company.' (op. cit.: 30). BHP Billiton reacted by serious investment of resources and of high-level attention in order to safeguard its image, legitimacy and profits. It responded to the demand from communities and NGOs for more intensive citizen participation. The launch of the Dialogue Table... [paved] the way for binding decisions...' (op. cit.: 45). The role of Oxfam was vital, including in enhancing the readiness and skills for mutual listening and open negotiation, of both the mining company and the local communities. Some mining managers and some local leaders were sent to India to observe localities where mining companies and local communities had found ways to acceptably coexist.

Large-scale mining projects offer to local communities definite negative effects in the short run-including environmental damage and loss of access to some lands and waters -in return only for promises of possible longer-term benefits that depend on many uncertain factors and that are often (and overwhelmingly so in Peru) not corroborated by known prior experiences (Tanaka 2007; Merino 2008). The local community will surely bear many costs, but lacks assurance on its share in economic benefits, including because of the national state's insistence on national priorities and on state sovereignty over natural resources. Conflict frequently emerges nowadays where local rights explicitly claimed by communities were ignored by the duty bearers: the mining company and the state, who have typically originally proceeded exclusively in terms of the perspectives of, respectively, pursuit of short-term profit and maximization of national monetized net product. Transformation of conflict is possible where there are 'duty bearers committed to make institutional changes by negotiating the differences between the mining company and the local communities, and where meaningful participation from the communities took place' (Merino 2008: 41; Echave et al. 2006, 2009; Tanaka 2007). In particular, fruitful transformation is helped when some allies of the local communities have connections to the countries where the mining companies are based, and can capture attention there for the dispute (Merino 2008). Besides exerting pressure, a key role of the external facilitators is to help strengthen amongst the conflicting parties their willingness and ability to listen, mutual respect, and readiness and skills to negotiate. At Tintaya, the principle of local consent too was implicit as a priority concern, even if not an absolute commitment, in the agreement between the mining company and the communities.

Analysis of the Tintaya case that seeks a blueprint for harder cases certainly risks overoptimism; but it shows a set of relevant factors and linkages. The Tintaya negotiation did not rely on injection of substantial new material and financial resources to the region. It instead involved strategic application of intellectual and organizational resources by several NGOs-local, national, and international-that triggered counterpart intellectual and organizational contributions from the mining company, leading to a somewhat more equitable and sustainable allocation of the material benefits being generated by the mine. As in the Orme dam case, application of these additional intellectual and organizational resources extended the set of identified alternatives, to show possibilities that were mutually beneficial compared to a conflict scenario. And the processes of mutual familiarization allowed convergence on mutually agreeable compromises rather than the sort of ongoing conflict over the division of potential benefits that is likely when the bargaining partners lack mutual consideration and respect.

A model emerges of an institutionalized consensus-building approach, based on a combination of ethical and economic reasons (Merino 2008). First, the local community must have the right to participate in all the phases of projects that will have a major effect on its environment, 
living conditions and human security. Such participation helps to guarantee that communities benefit from extractive industry in their localities. Second, whether or not local communities have 'indigenous' status and whatever is or is not stated yet in international law, there is widespread demand from communities to decide if they want projects on their lands, and a principle of agreement-building should be incorporated for new projects, to prevent or transform social conflicts. Without a 'social license' from the communities, projects face major extra risks and costs. Recognition of this principle should motivate granting of the equally necessary 'corporate license' (de Wet's phrase): the investor business's commitment to respect local needs and rights. Views are divided over whether the local community should have not only a right of meaningful participation and ample compensation but a formal right of veto. A veto right might sometimes inhibit meaningful negotiation. The Tintaya case suggests also how it may be unnecessary when wellstructured negotiations can create a path that is mutually beneficial as compared to one of confrontation. In the absence of local community vetos Penz et al. (2011) stress the necessity of access, when required, to neutral competent mediation and arbitration.

\section{A HUMAN RIGHTS APPROACH: RESPONSIBILITY ETHICS ADVANCED BY SOCIAL MOVEMENTS}

We saw a note of despair in some of the anthropological literature on displacement. The record shows sharply conflicting immediate interests, severe victimization of weaker groups, and little respect for paper guidelines. Economic cost-benefit analysis is ready to systematically sacrifice the interests of groups with lesser economic weight for those with greater weight. Simple formulations of human rights allow veto of what would be widely beneficial steps, by small groups who reject them. Professional codes that call for attention to the interests of all, or of 'the community', are relevant but insufficient responses, even when they also acknowledge the ubiquity of conflicts and the prevalence of injustices (DeMartino 2011: 232). We need something more complex.

We saw greater optimism in a literature on principles that builds them into a proposed structured approach to decision-making. That literature-represented by the World Commission on Dams and taken further by Penz, Drydyk and Bose-is not only about paper principles for use by technocrats, including 'econocrats' (Self 1975). It stresses, first, why an approach that does not respect norms of distributive justice and self-determination is unlikely to securely and sustainedly achieve the development goals that 'managerialists' profess. (The recent stages of the Tintaya case may well illustrate this.) This proposition, of the growing ineffectiveness of bulldozer development in a world of widespread human rights expectations, represents a warning as well as a theorem: exploitative development is likely to generate local, national and international resistance. Second, this literature leads econocrats into a sphere of negotiation that recognises values neglected in the pleasurably self-contained calculus of cost-benefit analysis. Third, what gives potential force to paper principles is their backing by social movements: local movements and external movements that represent and support the claims of the weak, plus effective articulation between these organizations. Social movements channel expressions of value, identity and emotions, and demands for respect, not only calculations of material 'interests' (Guha, 1989; Stammers, 2009).

The somewhat greater optimism we saw in parts of the literature on mining reflects some cases of success that show such movements powerfully at work. The purported success story we looked at, around the Tintaya mine in Peru, concerned how to reasonably accommodate a mine in a locality, in a case which does not threaten displacement of most of the population. To generalise from Tintaya to other mining cases is problematic, and more so if we seek lessons for non-mining cases. Large dams demand displacement of entire communities, not just a few settlements. De Wet 
argued that experience shows there is no reliable way to adequately compensate those communities: the administrative systems cannot cope, there are few alternative jobs, people's lifeworlds are destroyed. And, in a case like India's Narmada Valley dams, the bigger economic stakes bring the involvement of higher levels of government who are unwilling to concede any authority to social movements and civil society organizations, local or foreign. Correspondingly, for social movements to attain major impact they must become able to influence and even enter national government: '...reading across [country] cases [including Bolivia, Ecuador, Guatemala, Peru] suggests that if movements are to shift public debates in ways that stand much chance of translating into significant change in the governance of mineral expansion, this is far more likely to occur if these movements become part of government. Such a move requires articulation between activism, social movements, and political parties', remark Bebbington et al. (2008a: 905).

We can extend this line of argument to highlight, as in the Risse-Sikkink (1999) model of the spread of human rights norms, the role of international movements that pressurise national governments, including through foreign governments, foreign investors and international financial institutions (IFIs). Risse and Sikkink's influential model describes the entry and absorption of international human rights norms concerning civil and political rights into the domestic practices of many countries which originally rejected the norms as Northern interference in their realm of sovereign self-determination. Influenced by ideas in the 'global human rights polity', domestic critics seek not only to directly impact national governments and other possible rights violators or delinquent duty-bearers, but also spread information and appeals back to the global human rights polity, which then brings intensified pressures to bear on violators and duty-bearers. This is 'the boomerang effect'. The model of change includes processes of socialization, as human rights ideas gradually become internalized as a language of justification. Risse and Sikkink propose that such interactions typically generate a 'spiral model' of change, proceeding through five stages (but with possible loops-back or standstills). At several of the stages the 'boomerang effect' is at work, building pressure to move to the next stage. Foreign actors are, it is true, less likely to express criticism over uncompensated or inadequately compensated displacement than they are over torture or military coups. However, human rights 'principles' - of non-discrimination, participation and inclusion, accountability and rule of law-as well as civil rights norms are highly relevant in the negotiations over projects that would displace people, more so than any norms about particular levels of compensation. Such human rights principles are now declared in most development cooperation lending. Pressure from social movements and civil society organizations also upon foreign private companies who aim to exploit resources is sometimes a significant weapon in campaigns for justice. The presence of funders who are less embarrassed by human rights criticisms, such as perhaps organizations from China presently, can weaken the mechanism; but international campaigns can influence corporations even when they are not formally constrained by IFI codes. A new statement of the model (Risse, Ropp, Sikkink 2013) refines its formulation, on the basis of widespread testing, and extends its range of application to a wider set of human rights.

The model involves connections between a series of agents, national and international. It thereby requires languages of mobilization that have cross-group and global appeal (cf. Khagram, 2004): hence the centrality of the language of human rights. Sometimes the campaigns are driven by an absolutist conception of rights that philosophers may find naïve. Inevitably, local activists employ less sophisticated formulations than do policy makers, legal theorists or academicians. But, presenting cases as involving bedrock values can provide energy and legitimacy for social movements and social entrepreneurs to fight for 'a seat at the table'. Once at the table they have a chance to change the terms of the debate: to change the vision of what are available alternatives 
and long-term interconnections, the vision of who are one's interlocutors, and even the interlocutors' conceptions of themselves. Absolutist formulations may help in mobilization and getting this place at the negotiation table, which then provides a learning space to promote the mutual respect and acceptance (especially from the duty-bearers' side) that are essential for flexibility and rethinking (Forester, 2009).

A human rights-based approach (HRBA) relies thus on promoting reasonableness and mutual adjustment by the parties. There are no guarantees that an HRBA will work, especially if it offers just a listing of human rights norms which may conflict with each other. Nor can such an approach substitute for relevant technical knowledge, good technical options and suitable institutional structures. But a human rights perspective helps by encouraging, sometimes even forcing, greater recognition of 'the other' by powerful groups, leading them at least to a more enlightened practice of self-interest. Human rights campaigns that increase duty bearers' degree of reasonableness can thereby increase readiness by the marginalized to come to stable accommodations, when they feel they are taken seriously and will gain a worthwhile share. This is what the proposals by the World Commission on Dams and Penz et al. rely on - not a technocratic method or a formal and absolute veto for local communities but rather the rights to be closely involved, well compensated, and treated with respect, which if not fulfilled will bring problems for the duty-holders. ${ }^{9}$ The approach stresses human rights principles of recognition, accountability and participation, not only human rights norms about living standards; for in the absence of the principles the norms can be marginalised and undermined. '...the right to claim accountability is fundamental to making other social and economic rights real' (Newell and Wheeler, 2006: 7).

Full compensation is in fact impossible when the displaced or potentially displaced are treated merely as objects; nothing then can compensate for loss of homeplace and identity. But during more participatory interaction the definitions of ' $l$ ' and 'we' can become modified. The ' $I$ ' and the community 'we' are now more than damaged objects whose wounds are to be patched or who are to be sacrificed for a greater good. They are agents who choose, fulfilling their fundamental human right to share in choosing, including choosing who they are. They may identify ways in which they can advantageously grow into new roles, modified personas. This understanding of people, as meaning-making agents, takes us far beyond the model of sovereign (provided they are monied) consumers with given preferences, that underlies economic cost-benefit analysis.

A case like Tintaya does not illustrate application of a disembedded philosophical formula. Rather it showed the working of processes of encounter, trust-building, legitimacy-building, and joint search for solutions, supported by pressures provided through the transnational 'boomerang effect'. The mechanisms may be summed up, with apologies to Theodore Roosevelt, as 'speak softly and carry a big boomerang'. They go beyond the Risse-Sikkink model, and give a scenario of possible change through the combination of local processes of encounter that lead to dialogue and a global human rights language of legitimacy that encourages alliances wider than narrow interest groups. The global language facilitates the institutionalization of the local processes. So, using Dwivedi's terms, we need both 'movementism' and an 'institutional'/'responsibility' approach. Social movements supported by civil society bodies are the engines to force progress, towards a more justifiable allocation of rights and responsibilities between various organizations and institutions; and the movements and networks involved must be international as well as local.

\footnotetext{
9 Sen (2009) similarly stresses the contributions of reasoned debate in the public arena towards establishing mutual awareness and recognition, communicating respect, and thus constituting a framework of cooperation.
} 
Displacement is an ethical problem. Where some observers fear it has no ethical solution, others suggest not just that the problem-obviously-is political (too), but that progress may be made through local and international mobilization, as triggers for democratic deliberation. A human rights-based approach synthesises these necessary features, for it is both an ethical discourse and a political strategy, which mobilizes groups and builds alliances nationally and internationally. That Dwivedi's influential 2002 review article of the literature on development-induced displacement never once used the term 'human rights' serves as an indicator of how rapidly human rights approaches have evolved and spread in recent years, with stress on human rights procedural principles and a de-absolutized treatment of human rights provision standards. The approach functions as both a language of protest and a framework for deliberation. Human rights thinking seems to have a central role in motivating and binding the intranational and international alliances that are needed, because of its relative familiarity, forcefulness and established institutionalization; and it can add a further vital ingredient, a stress on establishing the dialogical spaces and processes which are essential for increasing the levels of mutual understanding and trust between duty holders and the alliances that campaign for poor people at risk, and for strengthening the bases for shared creative thinking and for acceptable compromise.

\section{CONCLUSION: ECONOMISTS AS PROFESSIONALS WITH HUMAN RESPONSIBILITIES}

We began by noting how a professional economic ethics, one that takes seriously the obligation to seek to minimize harm, must examine the mechanisms by which economists influence people's lives, and must remember that compared to the face-to-face work of medical practitioners these mechanisms are more generalized and indirect. Economists must examine, therefore, their methods and methodologies and how these are used, including also by engineers, politicians, administrators and businessmen. We noted in particular the deep ethical inadequacy of economic cost-benefit analysis that relies on the potential compensation principle, in projects whose distribution of benefits is sharply skewed to the disadvantage of groups who are already disadvantaged. That the already disadvantaged groups could potentially be compensated for their further disadvantage engineered by the project, out of the gains generated by the project, is significant but not a sufficient basis to consider the project acceptable. To not require their actual compensation for major losses is to endorse unethical victimization of blameless groups and a concealed promotion of privilege.

Economists should include in their analyses attention to the actual distribution of costs and benefits, and to how far are courses of action consistent or inconsistent with universally declared human rights standards and principles, in the same way that other professions are expected to do. Just as economists should highlight the uncertainties regarding the data and predictive theories they use, and to what extent these uncertainties can affect conclusions, equally we must highlight the ethical assumptions of any valuation method used. However, the assumption in nearly all economic cost-benefit analyses that distribution can be ignored cannot be exonerated simply by stating it, as it leads in many cases to sanctioning proposals that infringe nationally and internationally endorsed human rights. We must be aware of, and explicit about, the special circumstances required for the Kaldor-Hicks criterion of potential compensation to be an ethically legitimate criterion of improvement. Stated relatively indulgently these conditions include that the criterion is applied exclusively to projects that bring only minor shifts in distribution, and that projects do not have a systematic tendency to disadvantage the same groups again and again; and, more strictly, that, in addition, the existing distribution of purchasing power is acceptable, for it 
influences the market values for required compensation. Economists should point out in addition the riskiness, in addition to the ethical questionability, of project plans which disproportionately provide gains to some groups, typically already privileged, and disproportionately impose pains on other groups, typically already under-privileged; such projects build insecure social foundations.

The notion of a profession includes the idea of recognition of responsibilities that correspond to the special status and influence of the profession's members. Economists must consider responsibilities to the publics whom they affect, as well as responsibilities to those who hire them. To suggest some required elements of an adequate professional economic ethics with special reference to economic development, this essay has drawn on ideas from human rights theory. Since important values can conflict, we recognised that assertion of human rights standards regarding mandatory outcomes and of a do-no-harm principle are not always adequate. We referred therefore also to other work in development ethics, regarding the meaning of 'responsible development', and to procedural human rights values, which are articulated as the so-called human rights principles including accountability, inclusive participation, and the right to receive good reasons.

As indicated at the outset, economists cannot leave ethical questions purely for an often absent notional 'colleague' from another discipline or for an authorized decision-maker who is rarely master of the issues at stake and the methods in play. A narrowly disciplinary definition of professional role is a way of abandoning ethics. We would find it unacceptable for doctors, and should find it unacceptable for economists too. 


\section{REFERENCES}

Alvares, C., and Billorey, R., 1988. Damming the Narmada, Penang: Third World Network/APPEN.

Arellano-Yanguas, J., 2008. A Thoroughly Modern Resource Curse? The New Natural Resource Policy Agenda and the Mineral Revival in Peru. Working Paper 300, IDS Sussex.

Baviskar, A., 2006. Foreword. Pp.xi-xxvi, in R. Dwivedi, 2006, Conflict and Collective Action, Delhi: Routledge.

Bebbington, A., et al. (L. Hinojosa, D.H. Bebbington, M.L. Burneo, X. Warnaars), 2008a. Contention and Ambiguity: Mining and the Possibilities of Development. Development and Change, 39(6), 887-914.

Bebbington, A., et al. (D.H. Bebbington, J. Bury, J. Lingan, J.P. Munoz, M. Scurrah), 2008b. Mining and Social Movements: Struggles over Livelihood and Rural Territorial Development in the Andes. World Development, 36(12), 2888-2905.

Berger, P., 1974. Pyramids of Sacrifice. New York: Basic Books.

Blaser, M., Feit, H. A. and McRae, G., editors. 2004. In The Way Of Development: Indigenous Peoples, Life Projects and Globalization. London and New York: Zed Books.

Cernea, M., 2000. Risks, Safeguards, and Reconstruction. In M. Cernea and C. McDowell (eds.), Risks and Reconstruction, pp. 11-55, Washington, DC: World Bank.

Cernea, M., 2008. Compensation and investment in resettlement. Can Compensation Prevent Impoverishment? Eds. M. Cernea \& H.M. Mathur, New Delhi: Oxford University Press.

Cernea, M., 2009. Financing for Development: Benefit-Sharing Mechanisms in Population Resettlement. Pp.49-76 in Development \& Dispossession, ed. A. Oliver-Smith, Santa Fe, NM: SAR Press.

DeMartino, G., 2011. The Economist's Oath. Oxford University Press

de Wet, C., 2009. Does Development Displace Ethics? The Dilemma Of Forced Resettlement. Pp.77-96 in Development \& Dispossession, ed. A. Oliver-Smith, Santa Fe, NM: SAR Press.

Downing, T., \& Garcia-Downing, C., 2009. Routine and Dissonant Cultures: A Theory about the Psycho-sociocultural Disruptions of Involuntary Displacement and Ways to Mitigate Them without Inflicting Even More Damage. Pp.225-253 in Development \& Dispossession, ed. A. Oliver-Smith. Santa Fe, NM: SAR Press.

Doyal, L, \& Gough, I., 1991. A Theory of Human Need. Macmillan.

Dwivedi, R., 2002. Models and methods in development-induced displacement. Development and Change, 33(4), 709-32.

Dwivedi, R., 2006. Conflict and Collective Action: The Sardar Sarovar Project in India. Delhi: Routledge.

Earthworks and Oxfam America, 2007. Golden Rules: Making the case for responsible mining. Oxfam America.

Echave, J. de, K. Keenan, M.K. Romero, A. Tapia, 2006. Dialogue and Management of Conflicts on Community Lands: The Case of The Tintaya Mine in Peru. Lima: CooperAcción.

Echave, J. de., A. Diez, L. Huber, B. Revesz, X. Ricard and M. Tanaka, 2009. Minería y Conflicto Social. Lima: CIESACDI-IDRC.

Flyvbjerg, B., 2008. Public Planning of mega-projects: overestimation of benefits and underestimation of costs. Ch.7 in Decision-making on Mega-projects, eds. H. Priemus, B. Flyvbjerg, B. van Wee. Cheltenham: Edward Elgar.

Forester, J., 2009. Dealing with Differences. New York: Oxford University Press.

Gasper, D., 2004. The Ethics of Development - from economism to human development. Edinburgh: Edinburgh University Press.

Gasper, D., 2009. Human Rights, Human Needs, Human Development, Human Security. Pp.329-355 in Ashgate Research Companion to Ethics and International Relations, ed. P. Hayden, Ashgate: Aldershot.

Gasper, D. and A.L. St.Clair (eds.), 2010. Development Ethics, Aldershot: Ashgate

Gasper, D.; A.L. St.Clair; A.V. Portocarrero 2013: The Framing Of Climate Change And Development: A Comparative Analysis of the Human Development Report 2007/8 and the World Development Report 2010. Global Environmental Change 23 (2013): 28-39.

Goulet, D., 1960. 'Pour une éthique moderne du développement', Développement et Civilisations, 3, September, 10-23.

Goulet, D., 1971. The Cruel Choice, New York: Atheneum.

Goulet, D., 2005. Global Governance, Dam Conflicts, and Participation. Human Rights Quarterly, 27, $881-907$.

Guha, R., 1989. The Unquiet Woods: Ecological Changes and Peasant Resistance in the Himalaya. Delhi: Oxford University Press. 
Kates, R., et al., 2006. Great Transition Values - Present Attitudes, Future Changes. Paper 9, Great Transition Initiative. http://www.gtinitiative.org/documents/PDFFINALS/9Values.pdf.

Khagram, S., 2004. Dams and Development - Transnational struggles for water and power. Ithaca, NY: Cornell University Press.

Maclntyre, A., 1977. 'Utilitarianism and Cost-Benefit Analysis', in K. Sayre (ed.), Values in the Electric Power Industry, Notre Dame: IN: Notre Dame Univ. Press, 217-37.

Malley, F., 1968. Le Père Lebret: L'économie au service des hommes, Paris: Cerf.

McNeill, D., and Lera St.Clair, A., 2009. Global Poverty, Ethics and Human Rights: The Role of Multilateral Organisations, London and New York: Routledge.

Menkel-Meadow, C., 1996. The Trouble with the Adversary System in a Post-Modern, Multi-Cultural World. William and Mary Law Review, 38, 5-44.

Merino, L., 2008. Community Right To Participate in Mining Policies with Reference to Tintaya and Rio Blanco Mining Conflicts in Peru. The Hague: Institute of Social Studies.

Newell, P., and Wheeler, J., 2006. Introduction. In: Newell, P., and Wheeler, J. (eds.), 2006. Rights, Resources and the Politics of Accountability. London: Zed, pp.1-36.

Oliver-Smith, A., 2009. Development and Dispossession. Pp.3-23 in Oliver-Smith, A. (ed.), 2009. Development \& Dispossession: The Crisis of Forced Displacement and Resettlement, Santa Fe, NM: SAR Press.

Oxfam Australia, 2007. Free, prior and informed consent: The role of mining companies. Carlton: Oxfam Australia. October 2007 edition.

Oxfam Australia, 2010. Guide to free prior and informed consent. Carlton: Oxfam Australia.

Penz, P., 1986. Consumer Sovereignty and Human Interests. Cambridge: Cambridge University Press. Reprinted 2008.

Penz, P., 2003. Development, displacement and international ethics, pp. 139-152 in P. Quarles van Ufford and A.K. Giri eds., A Moral Critique of Development, London: Routledge.

Penz, P., J. Drydyk, P. Bose, 2011. Displacement by Development - Ethics, Rights and Responsibilities, Cambridge University Press.

Perspectives, 2008. Abandoned: Development and Displacement. $2^{\text {nd }}$ edition. Delhi: Perspectives Team, Hindu College, Delhi University.

Porter, D., Allen, B., Thompson, G., 1991. Development in Practice. London: Routledge.

Risse, T. and Sikkink, K., 1999. 'The socialization of international human rights norms into domestic practices: introduction', in T. Risse, S.C. Ropp and K. Sikkink (eds.), The Power of Human Rights - International Norms and Domestic Change, pp.1-38, Cambridge: Cambridge Univ. Press.

Risse, T., S.C. Ropp and K. Sikkink (eds.), 2013. The Persistent Power of Human Rights - From Commitment to Complicance, Cambridge: Cambridge Univ. Press.

Scudder, T., 2005. The Future of Large Dams: Dealing with Social, Environmental, Institutional and Political Costs. London: Earthscan.

Self, P., 1975. Econocrats and the Policy Process: The politics and philosophy of cost benefit analysis. London: Macmillan.

Sen, A.K., 1982. Choice, Welfare and Measurement. Oxford: Basil Blackwell.

Sen, A.K., 2009. The Idea of Justice. London: Penguin.

Shue, H., 2006. Ethical Dimensions of Public Policy. Ch.35 in M. Moran et al (eds), The Oxford Handbook of Public Policy. Oxford University Press.

Singh, S.K, 1990. Evaluating Large Dams in India. Economic and Political Weekly, March 17, pp. 561-574.

Stammers, N., 2009. Human Rights and Social Movements. London: Pluto Press.

Tanaka, M., 2007. The mining conflicts can not be resolved, but only transformed. Economia y Sociedad. Lima: CIES.

Winship, C., 2006. Policy Analysis as Puzzle Solving. Pp. 109-23 in M. Moran, M. Rein, R. Goodin eds., Oxford Handbook of Public Policy, Oxford University Press.

World Commission on Dams, 2000. Dams and Development. London: Earthscan.

\footnotetext{
${ }^{\mathrm{i}}$ Acknowledgements: I would like to record my indebtedness, for helpful discussions, materials and suggestions, to Chris de Wet, Jay Drydyk, the late Ranjit Dwivedi, John Forester, Lenny Merino, P.V. Poruthuyil, George

DeMartino and seminar audiences in Lima, Ithaca, Porto Alegre, and Cambridge UK.
} 